\title{
Hydrothermal Synthesis of Alkali-Containing Hydrated Vanadium Oxides with Layered Structures
}

\author{
Yoshio OKA, Takeshi YAO* and Naoichi YAMAMOTO \\ Department of Chemistry, College of Liberal Arts and Sciences, Kyoto University, \\ Yosida-nihonmatsu-cho, Sakyo-ku, Kyoto-shi 606 \\ * Department of Industrial Chemistry, Faculty of Engineering, Kyoto University, \\ Yoshida-hommachi, Sakyo-ku, Kyoto-shi 606
}

\section{層状構造をもつアリカリ含有水和バナジウム酸化物の水熱合成}

\author{
岡 与志男・八尾 健* · 山本 直一 \\ ( 京都大学教養部化学教室, 606 京都市左京区吉田二本松町 $)$ \\ * 京都大学工学部工業化学教室, 606 京都市左京区吉田本町)
}

\begin{abstract}
Hydrated vanadium oxides containing alkali ions were prepared by the hydrothermal treatment of VOSO, aqueous solutions. The products adopted layered structures with a general composition of $A_{0.3} V_{2} \mathrm{O}_{5} \cdot n \mathrm{H}_{2} \mathrm{O}\left(\mathrm{A}=\mathrm{Na}, \mathrm{K}, \mathrm{Rb}, \mathrm{Cs}\right.$ and $\mathrm{NH}_{4} ; n=$ 0.6-1.2). The layer spacings were around $11 \AA$. They were almost unchanged for the compounds of different alkali ions. The layered structures are considered to be composed of the $\mathrm{V}_{2} \mathrm{O}_{5}$ layers intercalated with water molecules and alkali ions. Dehydration by heating or evacuation caused transitions into the phases where the layer spacings contracted by 1 to $2 \AA$ leading to the values proportional to the size of alkali ions.

[Received July 5, 1990; Accepted August 31, 1990]
\end{abstract}

Key-words : Hydrothermal synthesis, Vanadium oxide, Alkali ion, Hydrate, Layered structure, Intercalation, Phase transition

\section{Introduction}

Hydrated vanadium oxides based on the structure of $\mathrm{V}_{2} \mathrm{O}_{5}$ adopt layered structures intercalated by water molecules. They have various layer spacings depending on the degrees of hydration. $\mathrm{V}_{2} \mathrm{O}_{5}$ gels are familiar examples of this class of compounds. ${ }^{1 / 4)}$ The present authors studied the hydrothermal synthesis of the hydrated vanadium oxides that were in regular crystalline states but not in colloidal states and also reported multi-step phase transitions in a dehydration process. ${ }^{5}$ In the present study, the hydrated vanadium oxides containing alkali ions were prepared by a hydrothermal method. It was found that the layer spacings were nearly constant for the compounds with different alkali ions. Dehydration caused the contraction of the layer spacings to the values depending on the size of alkali ions.

\section{Experimental}

Hydrothermal treatment was conducted as follows, $\mathrm{VOSO}_{4}$ aqueous solutions containing alkali ions in equimolar amounts with $\mathrm{VOSO}_{4}$ were sealed in pyrex tubes and were reacted at $200^{\circ}$ to $220^{\circ} \mathrm{C}$ for $30 \mathrm{~h}$. The products were separated by filtration and were characterized by X-ray diffraction using $\mathrm{CuK} \alpha$ radiation, TG-DTA, absorptiometry and high-temperature $\mathrm{X}$-ray measurements as described in our previous paper. ${ }^{5}$ Alkali and nitrogen contents were measured by flame emission spectroscopy and combustion method, respectively.

\section{Results and discussion}

Figure 1 shows $\mathrm{X}$-ray diffraction patterns of the products for $\mathrm{Na}, \mathrm{K}, \mathrm{Rb}, \mathrm{Cs}$ and $\mathrm{NH}_{4}$ ions. The patterns appear almost identical for the compounds with different alkali ions. Also the $00 l$ reflections are exclusively seen in Fig. 1 indicating that the compounds are of layered structures. It should be noticed that the layer spacings are almost constant; $10.80 \AA$ for $\mathrm{Na}, 10.86 \AA$ for $\mathrm{K}$, $10.93 \AA$ for $\mathrm{Rb}, 10.92 \AA$ for $\mathrm{Cs}$ and $10.98 \AA$ for $\mathrm{NH}_{4}$. Thus the phases of the alkali compounds may be isostructural and are designated as the $11 \AA$ phase. As shown in Fig. 2, some samples of the $\mathrm{Na}$ compound had the layer spacing of $13.7 \AA$ in a wet state which changed to $10.80 \AA$ by 


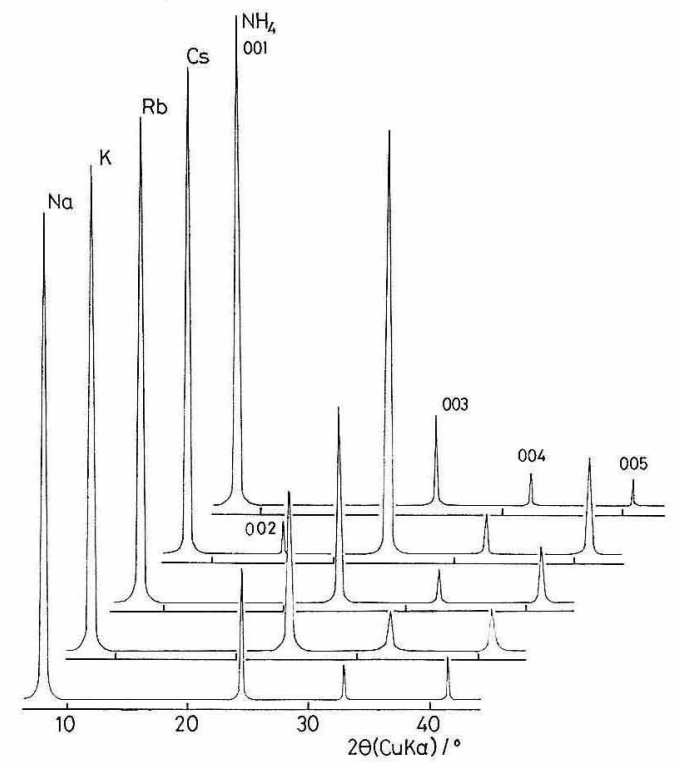

Fig. 1. X-ray diffraction patterns of the alkali compounds for $\mathrm{Na}, \mathrm{K}, \mathrm{Rb}, \mathrm{Cs}$ and $\mathrm{NH}_{4}$ ions.

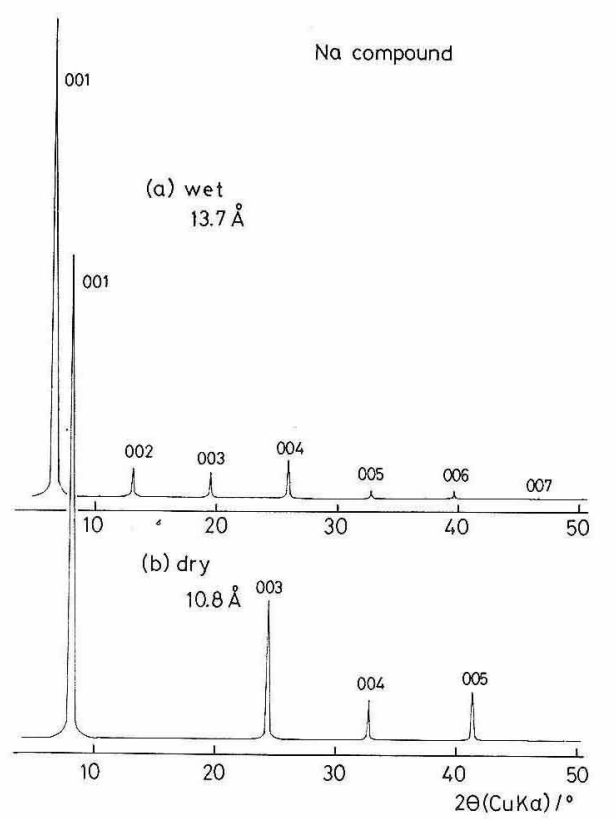

Fig. 2. X-ray diffraction patterns of the $\mathrm{Na}$ compounds in (a) wet and (b) dry form.

drying. That is, a more hydrated phase exists like the phase I' of the hydrated vanadium oxides in our previous paper, ${ }^{5)}$ which is called the $13.7 \AA$ phase hereafter. As shown in Fig. 3 of an SEM picture for the $\mathrm{Na}$ compound, the particle shape of the alkali compounds is a thin ribbon reflecting layered structures. The compositions of the alkali compounds are listed in Table 1. They are gener-

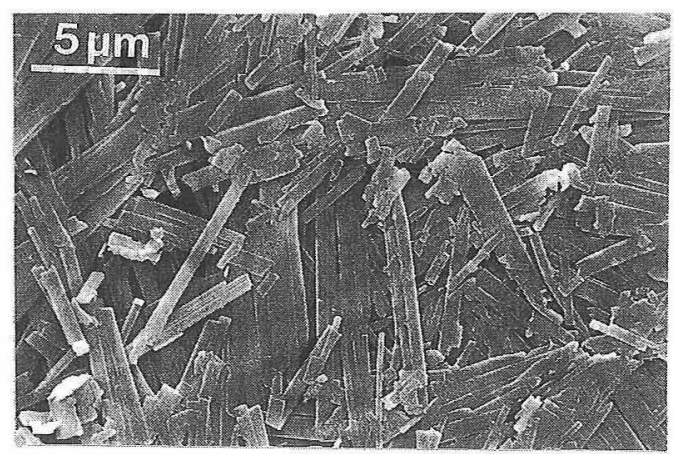

Fig. 3. SEM picture of the $\mathrm{Na}$ compound.

Table 1. Compositions of the alkali compounds,

\begin{tabular}{lcc}
\hline alkali compound & composition & $\begin{array}{c}\text { oxidation number } \\
\text { of } \mathrm{V}\end{array}$ \\
\hline $\mathrm{Na}$ compound & $\begin{array}{l}\mathrm{Na}_{0} 0.27 \mathrm{~V}_{2} \mathrm{O}_{5} \cdot 01 \cdot 1 \cdot 17 \mathrm{H}_{2} \mathrm{O}^{*} \\
\mathrm{Na}_{0.37} \mathrm{~V}_{2} \mathrm{O}_{4} \cdot 99 \cdot 1 \cdot 03 \mathrm{H}_{2} \mathrm{O}\end{array}$ & 4.85 \\
& 4.80 \\
$\mathrm{~K}$ compound & $\mathrm{K}_{0.32} \mathrm{~V}_{2} \mathrm{O}_{5} \cdot 01 \cdot 0 \cdot 91 \mathrm{H}_{2} \mathrm{O}$ & 4.85 \\
$\mathrm{Rb}$ compound & $\mathrm{Rb}_{0.30} \mathrm{~V}_{2} \mathrm{O}_{5.02} \cdot 0.81 \mathrm{H}_{2} \mathrm{O}$ & 4.87 \\
$\mathrm{Cs}$ compound & $\mathrm{Cs}_{0.34} \mathrm{~V}_{2} \mathrm{O}_{5.02} \cdot 0.67 \mathrm{H}_{2} \mathrm{O}$ & 4.84 \\
$\mathrm{NH}_{4}$ compound & $\left(\mathrm{NH}_{4}\right)_{0.28} \mathrm{~V}_{2} \mathrm{O}_{5} \cdot 02 \cdot 1.03 \mathrm{H}_{2} \mathrm{O}$ & 4.88 \\
\hline${ }_{\text {for the samples taking the } 13.7 \AA}$ phase in a wet form.
\end{tabular}

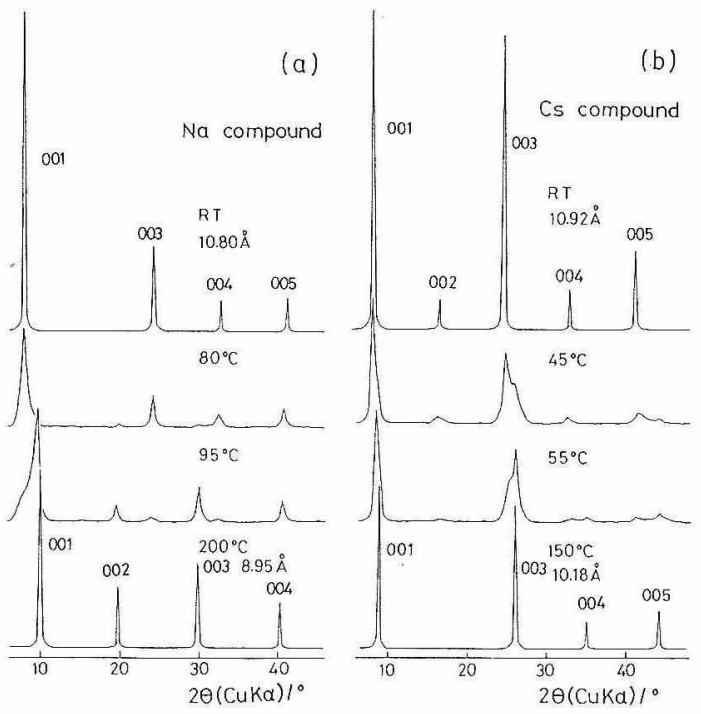

Fig.4. High-temperature $\mathrm{X}$-ray diffraction patterns for (a) the $\mathrm{Na}$ compound and (b) the $\mathrm{C}$ s compound.

ally expressed as $\mathrm{A}_{0.3} \mathrm{~V}_{2} \mathrm{O}_{5} \cdot n \mathrm{H}_{2} \mathrm{O} \quad(\mathrm{A}=\mathrm{Na}, \mathrm{K}$, $\mathrm{Rb}, \mathrm{Cs}$ and $\left.\mathrm{NH}_{4} ; n=0.6-1.2\right)$. The oxidation number of $\mathrm{V}$ is around 4.85, implying that $\mathrm{V}^{5+}$ ions were reduced to $\mathrm{V}^{4+}$ by the amount of alkali ions to conserve the composition of $\mathrm{V}_{2} \mathrm{O}_{5}$.

Figure 4 shows high-temperature $\mathrm{X}$-ray patterns of the $\mathrm{Na}$ and $\mathrm{Cs}$ compounds. On the dehydration by heating, the $11 \AA$ phases were changed into 


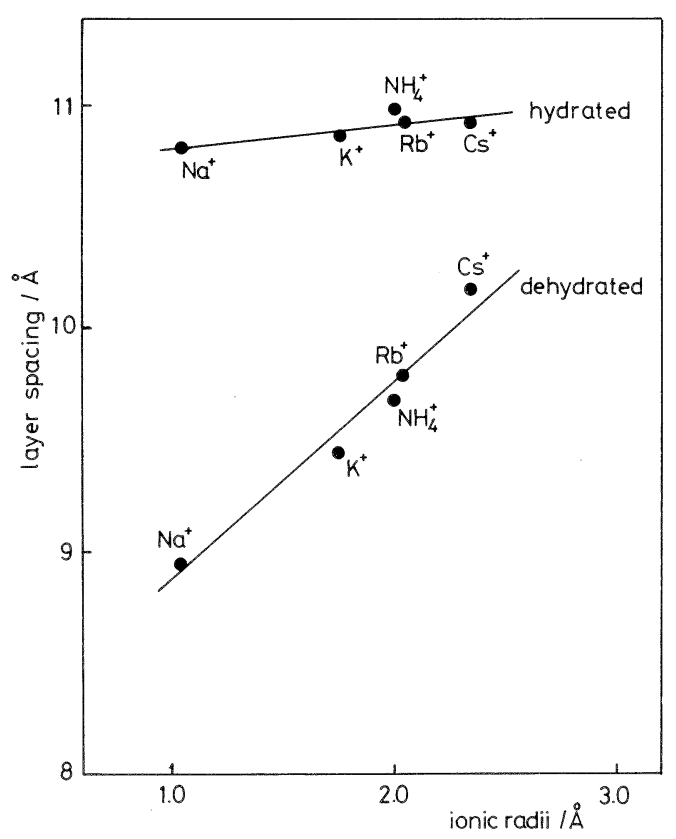

Fig. 5. Layer spacings plotted against ionic radii for the $11 \AA$ phases and the dehydrated phases.

those with smaller layer spacings and the dehydrated phases persisted to the decomposition of the layer phases. Almost identical behavior was oberved in other compounds. The dehydrated phases were also obtained by evacuation at room temperature except for the $\mathrm{Na}$ compound in which the dehydration proceeds at temperatures higher than in other alkali compounds. The values of the layer spacings of the dehydrated phases varied with the alkali ions; $8.95 \AA$ for $\mathrm{Na}, 9.45 \AA$ for $\mathrm{K}$, 9. $78 \AA$ for $\mathrm{Rb}, 10.15 \AA$ for $\mathrm{Cs}$ and $9.63 \AA$ for $\mathrm{NH}_{4}$. As shown in Fig. 5, the plot of the layer spacings against ionic radii of the alkali ions ${ }^{6}$ gives a linear relationship, that is, the layer spacings increase as the size of alkali ions becomes larger. It is concluded that the size of alkali ions dominates the layer spacings of the dehydrated phases and as also shown in Fig. 5 this is not the case for the $11 \AA$ phase.

Layer phases of hydrated $\mathrm{V}_{2} \mathrm{O}_{5}$ containing alkali ions except $\mathrm{Li}^{+}$were formed by the hydrothermal treatment. The $11 \AA$ phase and $13.7 \AA$ phase of Fig. 2 may be related to the phases of intercalated $\mathrm{V}_{2} \mathrm{O}_{5}$ gels for metallic cations reported by Livage et al. " They studied intercalation of various mono- and divalent cations into $\mathrm{V}_{2} \mathrm{O}_{5}$ gels and found that intercalated phases for monovalent ions had $11 \AA$ spacing and those for

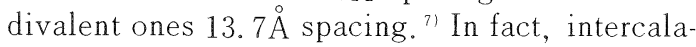
tion of, for example, $\mathrm{K}^{+}$into the phase I of our previous paper ${ }^{5}$ yielded the $11 \AA$ phase but the product had lower crystallinity than that by the hydrothermal method. ${ }^{8)}$ The present hydrothermal method produced well-crystallized phases suited for structure analysis and the study to elucidate the layered structures of the alkali compounds is in progress.

Acknowledgements The authous are grateful to.Professors K. Kosuge, T. Ohtani, Y. Ueda and N. Nakayama for their continuing interest and encouragement. The present work was partly supported by Grant-in-Aid for General Scientific Research (B) (No.01470073) from the Minsitry of Education, Science and Culture.

\section{References}

1) P. Aldebert, N. Baffier, N. Gharbi and J. Livage, Mater. Res. Bull., 16, 669-76 (1981).

2) J. J. Legendre and J. Livage, J. Colloid Interface Sci., 94, 75-83 (1983).

3) J. Legendre, P. Aldebert, N. Baffier and J. Livage, J. Colloid Interface Sci., 94, 84-89 (1983).

4) P. Aldebert, H. W. Hasslin, N. Baffier and J. Livage, J. Colloid Interface Sci., 98, 478-83 (1984).

5) Y. Oka, N. Yamamoto, T. Ohtani and T. Takada, Seramikkusu Ronbunshi, 97, 1441-45 (1989).

6) R. D. Shannon and C. T. Prewitt, Acta Cryst., B 25, 925-46 (1969).

7) A. Bouhaouss, P. Aldebert, N. Baffier and J. Livage, Rev. Chim. Miner., 22, 417-26 (1985).

8) Y. Oka and N. Yamamoto, unpublished work. 